\title{
Det vanskelige ordet angivelig
}

\author{
Ut fra vanlig språkbruk er det forståelig at et ord som angivelig kan oppfattes som ydmykende, \\ mener Rådet for legeetikk. Er det slik?
}

IDE

Engelsk oversettelse på www.tidsskriftet.no

Leger bruker ofte uttrykket angivelig for å poengtere at det som er journalført, bygger på pasientens egne opplysninger. De oppfatter ordet som nøytralt - det innebærer at legen verken kan bekrefte eller avkrefte om det som fortelles er sant eller ikke. Visstnok anvendes på liknende måte (1).

Rådet for legeetikk beskrev nylig en sak der en pasient følte seg krenket over at ordet angivelig var brukt om noe hun hadde fortalt under opptaket av anamnesen. Hun oppfattet ordbruken som mistenkeliggjøring og at legen egentlig ikke trodde på det hun fortalte. Rådet skrev at ut fra vanlig språkbruk er det forståelig at et ord som angivelig kan oppfattes som ydmykende, og det er grunn til å anbefale leger å velge mer nøytrale ord og uttrykk, f.eks. «pasienten forteller at» (1).

Det er lett å være enig i at dersom pasienter oppfatter legens ord som krenkende, bør man unngå slike ord. Men hvordan kunne det gå slik med ordet angivelig?

\section{Angivelig $=$ løgnaktig?}

Bruken av ordet angivelig ble nylig diskutert $i$ en annen sammenheng: Hvordan omtaler medier anmeldte sedelighetsforbrytelser? Når en anmeldelse foreligger, heter det ofte at det angivelig er begått et overgrep. Med andre ord: «Det er ikke sikkert det er sant», og at man med slik ordbruk stempler anmelderens rapportering som løgnaktig (2).

Angivelig betyr ifølge Bokmålsordboka «påstått, etter sigende» og er dannet av verbet ang $i=$ «opplyse om, nevne, tilkjennegi». Hvis jeg sier at «NN var angivelig hindret på grunn av sykdom», så forteller jeg at denne grunnen er angitt av vedkommende. Jeg tar ikke standpunkt til utsagnets sannhetsgehalt, dvs. om han var syk, eller om han bare forega å være syk. Leseren får beskjed om at jeg refererer, jeg innestår ikke for at personen faktisk var syk (2). Men enkelte, inkludert Rådet for legeetikk, mener at jeg dermed sier: «Stol ikke på NN, han var nok ikke syk.»

Kan man unngå slike uønskede konnotasjoner? Når jeg skriver: «NN sier at han er syk», da refererer jeg NNs oppfatning, men jeg innestår ikke for den. Hvis jeg noterer: «NN er angivelig syk» - betyr da det at han sannsynligvis ikke er syk? I rettslige tilfeller gjelder det å uttrykke seg slik at man unngår å konstatere straffeskyld før eventuell tilståelse eller dom foreligger. Så lenge forholdet ikke er bevist, er det grunn til å uttrykke seg forsiktig (2).

Så hva skal man gjøre? I debatten ble det

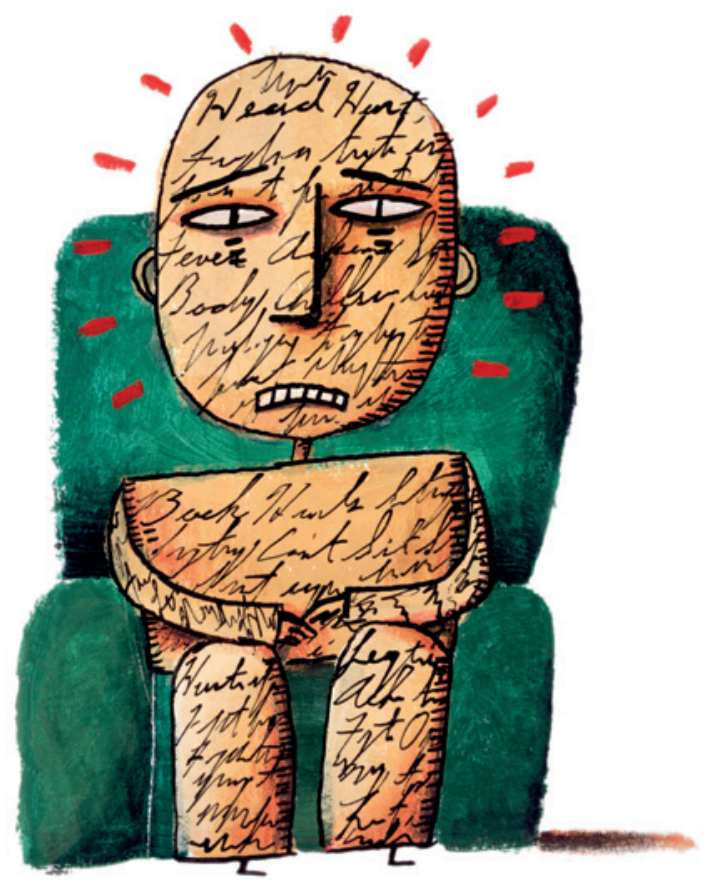

Illustrasjon James Yang/Images.com/Corbis/NTB scanpix

foreslått å erstatte angivelig med det juridiske verbet påstå («den påståtte voldtekten»), men det løser ikke problemet. I allmennspråket betyr påstå («hun påstår at hun er voldtatt») omtrent det samme som «hun sier det, men vi tror henne ikke» (2). Bedre enn ordene angivelig eller hevde er det ikke.

\section{Pasienten forteller}

Rådet anbefalte å skrive «Pasienten forteller at...» (1). Det er altså pasientens fortelling. Men har ikke også ordet fortelling en negativ konnotasjon? For meg har fortelling et snev av fiksjon over seg, ja, det kan i grunnen nærme seg fantasi, diktning og eventyr. En fortelling kan være sann eller ikke, det er ikke godt å vite. Kanskje er det da bedre med «Pasienter sier at...» eller «Ifølge pasienten...». Men kommer vi unna problemet? Opplysningene stammer fra pasienten og har dermed en annen status enn annen informasjon som legen har. Et annet alternativ er «Pasienten forklarer...» (3), men det gir meg assosiasjoner til avhørssituasjoner.

Diskusjonen minner litt om det Steven Pinker kaller «den eufemistiske tredemølle», dvs. at belastede ord erstattes med andre ord som igjen byttes ut med nye. Et eksempel er hvordan krøpling ble erstattet av vanfør $>$ handicappet $>$ funksjonshemmet $>$ person med funksjonshemning $>$ person med ned- satt funksjonsevne, eller hvordan gamlehjem ble til aldershjem $>$ sykehjem $>$ bolig for eldre $>$ bo- og rehabiliteringssenter (4). Man forsøker seg på omskrivninger og nye måter å si vanskelige ting på, men som regel varer det ikke lenge før de negative konnotasjonene følger etter, som nissen på lasset. Når et ord blir negativt ladet, finner vi på et nytt. Det blir fort en lang, lang rekke (4).

\section{Erlend Hem}

erlend.hem@medisin.uio.no

Tidsskriftet

Jeg takker Petter Gjersvik for nyttige kommentarer.

Erlend Hem (f. 1970) er dr.med. og assisterende redaktør i Tidsskriftet.

\section{Litteratur}

1. Markestad T. Ikke bruk «angivelig». Tidsskr Nor Legeforen 2010; 130: 523

2. Vinje F-E. Angivelig. Finn-Erik Vinjes blogg 10.2.2012. www. finnerikvinje. no/blog/? $\mathrm{p}=13644$ (4.4.2012).

3. Mellingen $\mathrm{HI}$. Om avisenes dekning av voldtekter http://senterforlikestilling.org/blogg-har-kvinnermindre-troverdighet-enn-menn/ (4.4.2012).

4. Halvorsen BE. Utgått på dato. A-magasinet 16.3.2012: $26-31$

Mottatt 15.4. 2012 og godkjent 12.6. 2012. Medisinsk redaktør Raida Ødegaard. 